\title{
Contribution to the Assessment of Suitability to Cheese Processing of Milk of Some Bovine Breeds (Prim'holstein, Montbeliarde, Flechvieh, Brown of Atlas) in the Region of Algiers
}

\author{
Lyes Ouabdesselam $^{1}$, Ahmed Saadi ${ }^{2}$, Khaled Harhoura ${ }^{3}$ \\ ${ }^{1}$ Center for Scientific and Technical Research in Physicochemical Analysis (C.R.A.P.C), \\ BP 384, RP 42004, Bou-Ismail, Tipaza, Algeria \\ ${ }^{2}$ National Veterinary Higher School of Algiers BP 161, Oued Smar, Algiers, Algeria \\ ${ }^{3}$ National Veterinary Higher School of Algiers BP 161, Oued Smar, Algiers, Algeria
}

\begin{abstract}
In order to reduce the import bill for milk, the government has opted to import dairy cows known for their high milk performance. The objective of the study is to evaluate the performance of these breeds in their new environment by comparing some chemical characteristics of the raw milk and the corresponding curd, as well as those of the brown Atlas present in the same farm. Then, evaluate recovery rates of Total Dry Extract (TSE) and Fat (MG) as well as ash in the curd. In this study, we looked at a dairy cattle farm in Algiers. It contains the aforementioned races. The selected heads were at the same number and stage of lactation. They received the same food. Our results show that Atlas Brown cows produce significantly higher fat and EST milk. That the curd of the Prim'Holstein cows and the Atlas Brown is richer in MG. That the Montbéliarde cows produce a milk with a ratio MG / Proteins of the most interesting curd, which translates into a good consistency of the curd. This ratio predisposes this breed to a better cheese processing ability.
\end{abstract}

Keywords: Cattle breeds, brown of Atlas, aptitude, milk, curdled.

\section{Introduction}

The characteristics of fresh cheese depend in part on the physico-chemical and bacteriological characteristics of the milks used in its manufacture [12].

These characteristics are of particular importance, especially when cheeses are made from small quantities of milk derived from a single herd in the case of farm products [1]. The objective of this study is divided into two parts. The first is to characterize and compare some chemical characteristics of the raw milk and the corresponding curd of the four races studied. The second is to evaluate the recovery rates in the curd of some chemical parameters (Fat, Dry Matter, Ash). In order to achieve our objectives, we were interested in the manufacture of fresh cheese from the individual milks obtained from a single operation for optimal control of the identical experimental conditions throughout the study period [7]. This operation consists of three breeds of imported cows recognized for their milk potential. These are the Prim'Holstein, the Montbéliarde and the Fleckvieh as well as the brown breed of the Atlas.

\section{Materiel and Methods}

\subsection{Presentation of the exploitation}

The farm in which the study was conducted consisted of fifty-three (53) dairy cows. It is located in LARBAA $(25 \mathrm{~km}$ southeast of Algiers). The method of breeding is semiintensive for Prim'Holshtein, Montbéliarde and Fleckvieh. Atlas brown cows are raised in extensive mode. They are housed only in the evening or during bad weather. Feeding of breeding cows is based on concentrate, hay with controlled food supplements and pasture. In this operation, trafficking is mechanized. It is done twice a day (4:00 am and 5:00 pm). Cows of the local population are treated only once a day (Monotraite). The zootechnical parameters of the farm are summarized in Table I.

Table I: Main zootechnical characteristics of the LARBAA cattle farm

\begin{tabular}{|c|c|c|c|c|}
\hline \multirow[t]{2}{*}{ Designation of Selected lots } & \multicolumn{4}{|c|}{ Breed } \\
\hline & Prim holshtein & Fleckvieh & Montbéliarde & Atlas brown \\
\hline Number of samples & 20 & 20 & 20 & 20 \\
\hline Alimentation & \multicolumn{4}{|c|}{ Pasture + hay + concentrate + supplement } \\
\hline Driving mode & \multicolumn{3}{|c|}{ Semi-intensive } & Extensive \\
\hline Milking mode & \multicolumn{4}{|c|}{ Mechanical } \\
\hline Number of lactation & \multicolumn{4}{|c|}{ Fourth lactation } \\
\hline Month of lactation & \multicolumn{4}{|c|}{ Between the second and the seventh month } \\
\hline Level of production /cow & $36 \mathrm{~kg} /$ day & $25 \mathrm{~kg} /$ day & $31 \mathrm{~kg} /$ day & $7 \mathrm{~kg} /$ day \\
\hline Number of milking & \multicolumn{3}{|c|}{ Two per day } & One per day \\
\hline
\end{tabular}

Volume 6 Issue 1, January 2017 


\section{International Journal of Science and Research (IJSR) \\ ISSN (Online): 2319-7064 \\ Index Copernicus Value (2015): 78.96 | Impact Factor (2015): 6.391}

\subsection{Conduct of Study}

The present study focused on five breed heads previously identified so as to constitute homogeneous batches in order to optimally neutralize the extrinsic parameters of variation of the milk composition (the same stage and the same number of lactation [3] [5], Having the same age and the same diet [1] [6] [14]). We collected samples over a period of four (4) weeks. The frequency of sampling is of the order of one sampling per head per week. This allowed us to eventually have a representative sampling of eighty (80) samples.

\subsection{The realization of the samples}

The samples are taken at the time of the milking in the morning (04h: 30 GMT +1 ). The cows are milked individually. At the end of each milking of a selected cow, we retrieve the can of the milking machine and we pour its contents collected in a clean bucket. We agitate the milk collected by means of a ladle with a hemispherical cap in stainless steel with handle in one piece. This ladle makes it possible to make the contents of the container perfectly homogeneous and allows to take $200 \mathrm{ml}$ of milk mixture per head. This volume is transferred to sterile labeled bottles. Each cow has its corresponding bottle. The bottles are immediately refrigerated in a cooler at $+4^{\circ} \mathrm{C}$. As soon as the samples have been collected, we send them to the laboratory to avoid any changes occurring after harvest [8] and we divide the samples in two equal quantities $(100 \mathrm{ml}$ each):

$100 \mathrm{ml}$ are analyzed fresh and $100 \mathrm{ml}$ are subsequently used for the production of fresh cheese. The manufacture is launched in the afternoon, ten hours after milking. P.s: volume of sample is of 1 liter / breed / week.

\subsection{Methodology of Cheese Manufacturing}

Individually collected milk is filtered through a slotted spoon Nylon fabric to remove foreign particles. The milk is then transferred to a Beaker. Each individual milk is put in a clean and identified container. Milk Is then heated in a water bath at $65^{\circ} \mathrm{C}$. for 30 minutes. The milk is cooled in a cold water bath at 20 to $25^{\circ} \mathrm{C}$. Using freeze-dried concentrated lactic leaven " MA 100 " (EZAL, Lacto-Labo, France), the milk undergoes maturation at ambient temperature (18 to 22 ${ }^{\circ} \mathrm{C}$.) The level of added yeast is $1 \%$. These yeasts are first put back into culture at a

Concentration of $2 \mathrm{~g} / 1$ in UHT milk at $27-33^{\circ} \mathrm{C}$ for 15 to 18 hours. After a maturation of 2 to 3 hours, corresponding to the decrease of the milk $\mathrm{pH}$ from 0.25 to 0.3 , the renneting is carried out at the same temperature and at a $\mathrm{pH}$ of 6.30 to 6.35 at a rate of $3 \mathrm{ml}$ of GRANDAY rennet extract $/ \mathrm{kg}$ of milk $(0.3 \mathrm{ml} / 100 \mathrm{ml})$. We have used the extract from Rennet GRANDAY to $520 \mathrm{mg}$ of chymosin / liter of extract (GRANDAY -ROGER, Sanofi, La France). 17 to 25 hours after the addition of the rennet, the curd obtained is left to drain spontaneously. This operation separates the whey from the curd. This operation lasts about 50 minutes. The curd is immediately refrigerated at $+4^{\circ} \mathrm{C}$. and analyzed in the laboratory of physicochemical analysis (maximum 12 hours later) [9].

N.b: In order to make the salting, two turns are provided followed by demolding and a deposit on grids; To have pieces of fresh cheese (JBEN) which will be kept at $+4^{\circ} \mathrm{C}$. But in our study, the turnings are not accompanied by salting so as not to distort the ash content of the curd.

\subsection{Laboratory analysis}

The analyzes concern the samples of the individual milk and the corresponding curd at the end of drainage. They include the determination of total dry extract (E.S.T), fat (MG), total proteins (PRO) and ash in both matrices by conventional chemical methods [2].

\subsection{Statistical analysis of data}

The comparison between the breeds studied for the different parameters is carried out by a Student test with an independent sample. The STATVIEW software is used for this test as well as for the calculations of the averages and the standard deviations.

\section{Results}

The results obtained in our study are presented in Table $\mathrm{N}^{\mathrm{o}}$ : II

Table No II: Chemical characterization of breast milks studied and influence on cheese yield (Mean \pm SD) (in g/ kg)

\begin{tabular}{|c|c|c|c|c|}
\hline Composition $(\mathrm{g} / \mathrm{kg}$ ) & Prim Holstein & Montbéliarde & Flechvieh & Brown of Atlas \\
\hline $\begin{array}{l}\text { Fresh milk: } \\
M G \\
P R O . T O T A L E S \\
\text { EST } \\
\text { CENDRES }\end{array}$ & $\begin{array}{l}36,6 \pm 1,76 \\
29,9 \pm 0,56 \\
120,2 \pm 2,83 \\
6,7 \pm 0,04 \\
\end{array}$ & $\begin{array}{l}24,3 \pm 1,33 \\
34,3 \pm 0,33 \\
115,0 \pm 2,11 \\
7,4 \pm 0,03 \\
\end{array}$ & $\begin{array}{l}23,6 \pm 0,65 \\
\mathbf{3 5 , 4} \pm \mathbf{0 , 3 5} \\
119,3 \pm 1,48 \\
7,4 \pm 0,03 \\
\end{array}$ & $\begin{array}{l}\mathbf{3 8 , 4} \pm \mathbf{0 , 8 7} \\
31,9 \pm 0,63 \\
\mathbf{1 2 5 , 5} \pm \mathbf{2 , 1 4} \\
\mathbf{8 , 8 \pm 0 , 0 1} \\
\end{array}$ \\
\hline G/PRO (\%) & $1,20 \pm 0,67$ & $0,68 \pm 0,34$ & $0,96 \pm 0,16$ & $1,24 \pm 0,34$ \\
\hline $\begin{array}{l}\text { Curdled: } \\
M G \\
T P \\
\text { EST } \\
\text { CENDRES }\end{array}$ & $\begin{array}{l}31,6 \pm 1,75 \\
18,2 \pm 0,58 \\
63,3 \pm 3,10 \\
5,4 \pm 0,03\end{array}$ & $\begin{array}{l}14,2 \pm 1,24 \\
15,2 \pm 0,72 \\
49,7 \pm 1,95 \\
6,5 \pm 0,02\end{array}$ & $\begin{array}{l}12,9 \pm 0,11 \\
\mathbf{1 8 , 6} \pm \mathbf{0 , 6 5} \\
60,1 \pm 0,63 \\
6,8 \pm 0,02\end{array}$ & $\begin{array}{l}\mathbf{3 3 , 5} \pm \mathbf{0 , 8 1} \\
10,3 \pm 0,53 \\
\mathbf{7 2 , 4} \pm \mathbf{1 , 6 6} \\
\mathbf{8 , 4} \pm \mathbf{0 , 0 2}\end{array}$ \\
\hline $\begin{array}{l}\text { Recovery rate in the curdled: } \\
M G \\
E S T \\
C E N D R E S\end{array}$ & $\begin{array}{l}78,73 \pm 23,14 \\
59,78 \pm 10,88 \\
81,27 \pm 3,18\end{array}$ & $\begin{array}{l}50,78 \pm 25,86 \\
43,20 \pm 19,53 \\
87,47 \pm 1,45\end{array}$ & $\begin{array}{l}52,08 \pm 22,28 \\
51,70 \pm 15,12 \\
92,31 \pm 2,49\end{array}$ & $\begin{array}{l}87,14 \pm 7,11 \\
31,41 \pm 14,05 \\
95,17 \pm 0,61\end{array}$ \\
\hline
\end{tabular}

Volume 6 Issue 1, January 2017 


\section{International Journal of Science and Research (IJSR) \\ ISSN (Online): 2319-7064}

Index Copernicus Value (2015): 78.96 | Impact Factor (2015): 6.391

\section{Interpretation and Discussion}

\subsection{The milk}

Our results show that milk from the Atlas Brown is significantly higher in fat (L / P: p $=0.47)$ and Total Dry Extract (L / P: p = 0.49) than in Primholstein. In terms of protein content, Atlas Brown has slightly lower levels (31.9 $\mathrm{g} / \mathrm{kg}$ ) than Fleckvieh $(35.4 \mathrm{~g} / \mathrm{kg}$ ) and Montbéliarde $(34,3$ $\mathrm{g} / \mathrm{kg}$ ) but with a statistical significance at a threshold of $5 \%$ $(\mathrm{L} / \mathrm{F}: \mathrm{p}=0.03, \mathrm{~L} / \mathrm{M}: \mathrm{p}=0.14)$. As regards the ash content, Atlas Brown milk has a content Significantly higher $(8.8 \mathrm{~g} /$ $\mathrm{kg})$ than the other breeds studied $(7.4 \mathrm{~g} / \mathrm{kg}$ for Montbéliarde as well as Fleckvieh and $6.7 \mathrm{~g} / \mathrm{kg}$ for Primholstein. These differences in composition between Atlas Brown and other breeds can be attributed in part to other factors of variation such as the mode of milking [10] (one milking in Atlas Brown, bitraite for Other breeds) and level of production ( $7 \mathrm{~kg} / \mathrm{d}$ for Atlas Brown, $25 \mathrm{~kg} / \mathrm{d}$ for the Fleckvieh breed, $31 \mathrm{~kg} / \mathrm{d}$ for the Montbéliarde breed and $36 \mathrm{~kg} / \mathrm{d}$ for the Primholstein breed). It is known that the milk of races with low milk potential in the Mediterranean zones is generally more concentrated in fat and fat solids and in protein than in breeds producing high temperatures [15]. Our results concerning the protein content of Atlas Brown milk do not corroborate the observations described in the scientific literature [15]. In fact, Atlas Brown milk with a low milk potential has a lower protein content than Montbéliarde and Fleckvieh. We can argue that the negative genetic correlation between milk production and The richness of major compounds concerns, in fact, only the fat and the defatted dry extract. Our observations confirm those described in the scientific literature [11]. It should be noted that the course of draining was more and more different between the breeds studied according to the literature [4]. .Nevertheless, it was ok for all races. This could be attributed to the ratio of protein to protein ratio of less than 1.4 in the four races studied [13] with 1.20 for Primholstein, 0.68 for montbéliarde, 0.66 for Fleckvieh, 1.24 For the Brune of the Atlas.

\subsection{The curdled}

Concerning MG and EST, our results show that the Atlas Brown curd is richer in MG (33.5 g / kg) and EST (72.4 g / $\mathrm{kg}$ ) than the Primholstein breed $(\mathrm{MG}=30.08 \mathrm{~g} / \mathrm{kg}$, TSE $=$ $63.4 \mathrm{~g} / \mathrm{kg}$ ) and Montbéliarde $(14.2 \mathrm{~g} / \mathrm{kg}, 49.7 \mathrm{~g} / \mathrm{kg})$ and Fleckvieh , $1 \mathrm{~g} / \mathrm{kg}$ ). Concerning protein levels, the milk curd of the Atlas Brown has the lowest content $(10.3 \mathrm{~g} / \mathrm{kg})$. Curds of the Primholstein breed and fleckvieh showed significantly higher grades $(18.2 \mathrm{~g} / \mathrm{kg}, 18.6 \mathrm{~g} / \mathrm{kg})$ at a statistical threshold of $5 \%$. Concerning the ash content, the Atlas Brown curd is rich $(8.4 \mathrm{~g} / \mathrm{kg})$ than that of the other breeds at a threshold of $5 \%(\mathrm{~L} / \mathrm{F}, \mathrm{L} / \mathrm{M}, \mathrm{L} / \mathrm{P}: \mathrm{P}=$ $<0.0001)$.

\section{CONCLUSION}

Our observations suggest that our Atlas Brown produces a milk rich fat and a total dry extract that other breeds studied. This could be explained by its very low milk yield ( $7 \mathrm{~kg} / \mathrm{d})$. Concerning the cheese-making abilities, we have found that the Atlas Brown makes it possible to obtain a curd richer in fat and lower in protein than other races. But the curd in this breed is the most softened and more melted compared to other races studied. Concerning the race Prim'holstein; The milk resulting from this breed is rich in major compounds (fat, protein) but less than that of the local breed. Nevertheless, the curd resulting from this breed is less firm and much more melted than that of milk from the Montbéliarde breed. Concerning the breed Montbéliarde, this breed produces a milk relatively rich in major compounds and allows to obtain a better consistency of the curd. The latter is firmer and more consistent than other targeted breeds. Data on the chemical composition of "milk" reveal lower fat and protein contents for Atlas Brown who may be related to its genetic make-up and / or its mode of conduct. We noted that the "curd" of the local breed, although richer in $\mathrm{MG}$, is less rich in protein. This results in a textured cheese softened. We found that the milk of the Prim'holstein breed is rich in major compounds (MG, protein) but that its curd is less firm and more melted than that of Montbéliarde. We found that the milk of the Montbéliarde breed is relatively rich in major compounds and that the "curd" is firmer and less melted than that of Primholstein milk. This confirms the choice of cheese producers for this breed. We found that the milk of Fleckvieh is less rich in fat but the richest in total protein and that the "curd", although less rich than that of Primholstein, is firmer and less melted. The aim of this type of research is to sensitize decision-makers on the opportunity to upgrade the milk of only a few bovine breeds in the form of fresh cheese for a better profitability of breeding.

\section{Thanks}

We would like to express our profound gratitude to Dr H. HAMIDOUCHE and We also thank all the staff of the Technical Institute of Livestock (I.T.E.L.V) for their kindness and for their invaluable help.

\section{References}

[1] AGABRIEL C., COULON J.B., JOURNAL C., SIBRA C., ALBOUY H. (1999). Variabilité des caractéristiques des fromages Saint-Nectaire fermiers : relations avec la composition du lait et les conditions de production. Lait, 79, p 291-302.

[2] AOAC: Offic ial methods of analys is.3 rd edition, Association of Offic ial Analytical Chemists, Washigton DC, US, 1990.

[3] AULDIST M.J., COATS S., SUTHERLAND B.J., MAYES J.J., MCDOWELL G.H., ROGERS G. (1996). Effects of somatic cell count and stage of lactation on raw milk composition and the yield and quality of Cheddar cheese. J. Dairy Res., 63,p 269-280.

[4] AULDIST M.J., MULLINS C., O'BRIEN B.,O'KENNEDY B.T., GUINEE T. (2002). Effect of cow breed on milk coagulation properties. Michwissenschaft, 57, p 140-143.

[5] BENSLIMANE S., DOGNIN-BERGERET M.J.,BERDAGUÉ J.L., GAUDEMER Y., (1990). Variation with season and lactation of plasmin and plasminogen concentrations in Montbéliard cows'milk.J. Dairy Res., 57, p 423-435.

\section{Volume 6 Issue 1, January 2017




\section{International Journal of Science and Research (IJSR) ISSN (Online): 2319-7064 \\ Index Copernicus Value (2015): 78.96 | Impact Factor (2015): 6.391}

[6] BOCQUIER F.,CAJAG. (2001): Production et composition du lait de brebis : Effets de l'alimentation, INRA prod.anim., 2001, 14, p 129-140.

[7] MARTIN B., COULON J.B. (1995). Facteurs de production du lait et caractéristiques des fromages.in : Influence des caractéristiques des laits de troupeaux et des pratiques fromagères sur les caractéristiques du Reblochon de Savoie fermier, revue Lait, $n^{\circ} 75$, P 133149.

[8] MATHIEU (1976).Modification du lait après récolte in : lait et produits laitiers Luquet F., et Bonjeanlinczowski. Edition technique et documentation. Lavoisier, Paris.

[9] MICHEL M., ROMAIN JEANTET, GERARD BRULE. (2000).Initiation à la technologie fromagère.Edition technique et documentation. Lavoisier. Paris. Codex 08.180 pages.

[10]POMIÈS D., MARTIN B., RÉMOND B.,BRUNSCHWIG G., PRADEL P., LAVIGNE R., HULIN S. (2003). La traite une fois par jour pendant 7 semaines de vaches laitières Prim'Holstein et Montbéliarde en milieu de lactation : performances zootechniques, qualité du lait et des fromages.Renc. Rech. Rum., 10, p 81-84.

[11]RABASCO A., SERRADILLA J.M., PADILLA J.A. SERRANO A. (1993). Genetic and No-génétic sources of variation in yield and composition of milk in Verara goats.Small ruminant res.11. p 151-161.

[12] REMEUF F., COSSIN V., DERVIN C., LENOIR J., TOMASSONE R. (1991). Relations entre les caractères physico-chimiques des laits et leur aptitude fromagère.in revue : Lait $\mathrm{n}^{\circ}: 71, \mathrm{p}$ 397-421.

[13] VERDIER-METZ I., COULON J.B., PRADEL P. (2001).Relationship between milk fat and protein contents and cheese yield. Anim. Res., 50, p 365-371.

[14] VERDIER-METZ I., COULON J.B., PRADEL P.,VIALLON C., BERDAGUE J.L. (1998). Effect of forage conservation (hay or silage) and cow breed on the coagulation properties of milks and on the characteristics of ripened cheeses. Journal Dairy Res., $65, \mathrm{p} 9-21$.

[15] VOUTSINAS L.P. ET PAPASS C.P., KATSIARI M.C. (1990): The composition of alpine goat's milk during lactation in Greece.J.Dairy res.57, p 41-51.

\section{Table}

\section{Calculation details by STATVIEW :}

Abbreviations :

P : Prim'Holstein, M : Montbéliarde, F : Flechvieh, L : Local Population 'Brown of Atlas ;

MG : Fat, PR : Totale Proteine, TDE : Total Dry Extract

Table III : Test-t unpaired series for MG Milk Group Variable : Breed

Theoretical ecart $=0$

\begin{tabular}{|l|l|l|l|l|}
\hline & Medium ecart & DDL & $\boldsymbol{t}$ & $\boldsymbol{p}$ \\
\hline F, L & 1,473 & 38 & 6,084 & $<, 0001$ \\
\hline F, M &,- 062 & 38 &,- 187 &, 8523 \\
\hline F, P & $-1,146$ & 38 & $-2,633$ &, 0122 \\
\hline L, M & 1,411 & 38 & 3,979 &, 0003 \\
\hline L, P &, 327 & 38 &, 721 &, 4753 \\
\hline M, P & $-1,084$ & 38 & $-2,140$ &, 0388 \\
\hline
\end{tabular}

Table III' : Info. du groupe pour MG lait Group Variable : Breed

\begin{tabular}{|l|c|l|l|l|l|}
\hline & Number & Moy. & Variance & Dév Std & Erreur Std \\
\hline $\mathbf{F}$ & 20 & 2,366 &, 423 &, 651 &, 145 \\
\hline $\mathbf{L}$ & 20 & 3,839 &, 749 &, 865 &, 194 \\
\hline $\mathbf{M}$ & 20 & 2,428 & 1,766 & 1,329 &, 297 \\
\hline $\mathbf{P}$ & 20 & 3,512 & 3,364 & 1,834 &, 410 \\
\hline
\end{tabular}

Table IV : Test-t unpaired series for PR Milk Group Variable : Breed Theoretical Ecart $=0$

\begin{tabular}{|l|l|l|l|l|}
\hline & Medium ecart & DDL & $\boldsymbol{t}$ & $\boldsymbol{p}$ \\
\hline F, L &, 347 & 38 & 2,162 &, 0370 \\
\hline F,M &, 111 & 38 & 1,039 &, 3053 \\
\hline F, P &, 545 & 38 & 3,689 &, 0007 \\
\hline L, M &,- 236 & 38 & $-1,493$ &, 1436 \\
\hline L, P &, 198 & 38 & 1,052 &, 2993 \\
\hline M, P &, 434 & 38 & $2,, 992$ & 0048 \\
\hline
\end{tabular}

Table IV' : Info. du groupe pour PR Milk Variable groupe : Breed

\begin{tabular}{|l|c|l|l|l|l|}
\hline & Number & Moy. & Variance & Dév Std & Erreur Std \\
\hline $\mathbf{F}$ & 20 & 3,542 &, 122 &, 349 &, 078 \\
\hline $\mathbf{L}$ & 20 & 3,195 &, 393 &, 627 &, 140 \\
\hline $\mathbf{M}$ & 20 & 3,431 &, 106 &, 326 &, 073 \\
\hline $\mathbf{P}$ & 20 & 2,997 &, 315 &, 561 &, 125 \\
\hline
\end{tabular}

Table V : Test-t unpaired series for TDE Milk Group Variable : Breeed

\begin{tabular}{|l|l|l|l|l|}
\hline & Medium ecart & DDL & $\boldsymbol{t}$ & $\boldsymbol{p}$ \\
\hline F, L &,- 616 & 38 & $-1,057$ &, 2970 \\
\hline F, M &, 428 & 38 &, 743 &, 4619 \\
\hline F, P &, 179 & 38 &, 249 &, 8049 \\
\hline $\mathbf{L}, \mathbf{M}$ & 1,044 & 38 & 1,555 &, 1283 \\
\hline $\mathbf{L}, \mathbf{P}$ &, 795 & 38 &, 996 &, 3256 \\
\hline $\mathbf{M}, \mathbf{P}$ &,- 249 & 38 &,- 314 &, 7554 \\
\hline
\end{tabular}

Table V': Info. du groupe pour TDE Milk Group Variable : Breed

\begin{tabular}{|l|c|l|l|l|l|}
\hline & Number & Moy. & Variance & Dév Std & Erreur Std \\
\hline F & 20 & 11,935 & 2,200 & 1,483 &, 332 \\
\hline $\mathbf{L}$ & 20 & 12,551 & 4,587 & 2,142 &, 479 \\
\hline $\mathbf{M}$ & 20 & 11,507 & 4,432 & 2,105 &, 471 \\
\hline $\mathbf{P}$ & 20 & 11,756 & 8,157 & 2,856 &, 639 \\
\hline
\end{tabular}

Table VI : Test-t unpaired series for CENDRES Milk Group Variable : Breed

\begin{tabular}{|l|l|l|l|l|}
\hline & Medium ecart & DDL & $\boldsymbol{t}$ & $\boldsymbol{p}$ \\
\hline F, L &,- 140 & 6 & $-7,668$ &, 0003 \\
\hline F, M &, 002 & 6 &, 113 &, 9137 \\
\hline F, P &, 075 & 6 & 2,852 &, 0291 \\
\hline L, M &, 142 & 6 & 8,902 &, 0001 \\
\hline L, P &, 215 & 6 & 10,043 & $<, 0001$ \\
\hline M, P &, 073 & 6 & 2,924 &, 0265 \\
\hline
\end{tabular}

Table VI ': Test-t unpaired series for CINDER Milk Group Variable : Breed

\begin{tabular}{|l|c|l|l|l|l|}
\hline & Number & Moy. & Variance & Dév Std & Erreur Std \\
\hline $\mathbf{F}$ & 20 &, 740 &, 001 &, 034 &, 017 \\
\hline $\mathbf{L}$ & 20 &, 880 &, 0002 &, 014 &, 007 \\
\hline $\mathbf{M}$ & 20 &, 738 &, 001 &, 029 &, 014 \\
\hline $\mathbf{P}$ & 20 &, 665 &, 002 &, 040 &, 020 \\
\hline
\end{tabular}




\section{International Journal of Science and Research (IJSR) \\ ISSN (Online): 2319-7064}

Index Copernicus Value (2015): 78.96 | Impact Factor (2015): 6.391

Table VIII : Info. du groupe pour MG Curdled Group Variable : Breed

\begin{tabular}{|l|c|l|l|l|l|}
\hline & Number & Moy. & Variance & Dév Std & Erreur Std \\
\hline $\mathbf{F}$ & 20 & 1,291 &, 504 &, 710 &, 159 \\
\hline $\mathbf{L}$ & 20 & 3,354 &, 651 &, 807 &, 180 \\
\hline $\mathbf{M}$ & 20 & 1,423 & 1,544 & 1,243 &, 278 \\
\hline $\mathbf{P}$ & 20 & 3,008 & 3,381 & 1,839 &, 411 \\
\hline
\end{tabular}

Table IX : Test-t unpaired series for PR Curdled Group Variable : Breed

\begin{tabular}{|l|l|l|l|l|}
\hline & Medium ecart & DDL & $\boldsymbol{t}$ & $\boldsymbol{p}$ \\
\hline F, L &, 823 & 38 & 4,411 & $<, 0001$ \\
\hline F,M &, 344 & 38 & 1,588 &, 1206 \\
\hline F, P &, 041 & 38 &, 211 &, 8342 \\
\hline L, M &,- 478 & 38 & $-2,396$ &, 0216 \\
\hline L, P &,- 782 & 38 & $-4,452$ & $<, 0001$ \\
\hline M, P &,- 303 & 38 & $-1,462$ &, 1521 \\
\hline
\end{tabular}

Table IX' : Info. du groupe pour PR Curdled Group Variable : Breed

\begin{tabular}{|l|c|l|l|l|l|}
\hline & Number & Moy. & Variance & Dév Std & Erreur Std \\
\hline $\mathbf{F}$ & 20 & 1,862 &, 418 &, 647 &, 145 \\
\hline $\mathbf{L}$ & 20 & 1,039 &, 277 &, 527 &, 118 \\
\hline $\mathbf{M}$ & 20 & 1,517 &, 520 &, 721 &, 161 \\
\hline $\mathbf{P}$ & 20 & 1,821 &, 339 &, 582 &, 130 \\
\hline
\end{tabular}

Table X : Test-t unpaired series for TDE Curdled Group Variable : Breed Ecart théorique $=0$

\begin{tabular}{|c|c|c|c|c|}
\hline & Medium ecart & DDL & $\boldsymbol{t}$ & $\boldsymbol{p}$ \\
\hline F, L & $-1,225$ & 38 & $-3,083$ &, 0038 \\
\hline F,M & 1,045 & 38 & 2,281 &, 0283 \\
\hline F, P &,- 028 & 38 &,- 040 &, 9686 \\
\hline $\mathbf{L}, \mathbf{M}$ & 2,270 & 38 & 3,962 &, 0003 \\
\hline $\mathbf{L}, \mathbf{P}$ & 1,197 & 38 & 1,523 &, 1361 \\
\hline $\mathbf{M}, \mathbf{P}$ & $-1,073$ & 38 & $-1,311$ &, 1977 \\
\hline
\end{tabular}

Table X' : Info. du groupe pour EST caillé Group Variable : Breed

\begin{tabular}{|l|c|l|l|l|l|}
\hline & Number & Moy. & Variance & Dév Std & Erreur Std \\
\hline F & 20 & 6,015 &, 396 &, 629 &, 141 \\
\hline $\mathbf{L}$ & 20 & 7,240 & 2,763 & 1,662 &, 372 \\
\hline $\mathbf{M}$ & 20 & 4,970 & 3,803 & 1,950 &, 436 \\
\hline $\mathbf{P}$ & 20 & 6,043 & 9,593 & 3,097 &, 693 \\
\hline
\end{tabular}

Table XII : Test-t unpaired series for CINDER Curdled Group Variable : Breed

\begin{tabular}{|l|l|l|l|l|}
\hline & Medium ecart & $\boldsymbol{D D L}$ & $\boldsymbol{t}$ & $\boldsymbol{p}$ \\
\hline F, L &,- 155 & 6 & $-13,638$ & $<, 0001$ \\
\hline F,M &, 037 & 6 & 2,666 &, 0372 \\
\hline F, P &, 142 & 6 & 8,626 &, 0001 \\
\hline L, M &, 192 & 6 & 13,141 & $<, 0001$ \\
\hline L, P &, 297 & 6 & 17,482 & $<, 0001$ \\
\hline M, P &, 105 & 6 & 5,547 &, 0015 \\
\hline
\end{tabular}

Table XII : Info. du groupe pour CINDER Curdled Group Variable : Breed

\begin{tabular}{|c|c|c|c|c|c|}
\hline & Number & Moy. & Variance & Dév Std & Erreur Std \\
\hline F & 4 &, 683 & $2,250 \mathrm{E}-4$ &, 015 &, 007 \\
\hline L & 4 &, 837 & $2,917 \mathrm{E}-4$ &, 017 &, 009 \\
\hline $\mathbf{M}$ & 4 &, 645 &, 001 &, 024 &, 012 \\
\hline $\mathbf{P}$ & 4 &, 540 &, 001 &, 029 &, 015 \\
\hline
\end{tabular}

